\title{
PENGENALAN POLA KARAKTER PLAT NOMOR KENDARAAN MENGGUNAKAN ALGORITMA MOMENTUM BACKPROPAGATION NEURAL NETWORK
}

\author{
Donny Avianto \\ Program Studi Teknik Informatika, Universitas Teknologi Yogyakarta \\ J1. Ringroad Utara, Jombor, Sleman 55285 \\ E-mail: donny@uty.ac.id
}

\begin{abstract}
Abstrak
Peningkatan jumlah kendaraan bermotor yang terus terjadi di Indonesia tiap tahunnya, membuat kebutuhan akan sistem yang mampu mengidentifikasi kendaraan secara otomatis atau sering disebut Sistem Lalu Lintas Cerdas juga ikut meningkat.Sistem ini dapat digunakan antara lain untuk menemukan kendaraan yang dicuri, pembayaran tiket parkir otomatis, dan menindak para pelanggar lampu merah. Kemampuan utama dari sistem tersebut adalah pengenalan plat nomor.Pada penelitian kali ini akan digunakan metode Momentum Backpropagation Neural Network untuk mengenali karakter dari suatu citra plat nomor kendaraan di Indonesia. Namun sebelumnya, citra plat nomor akan diubah menjadi citra biner. Citra biner kemudian disegmentasi untuk mengisolasi karakter-karakter yang akan dikenali. Terakhir dimensi citra hasil segmentasi akan direduksi menggunakan Haar Wavelet.Uji coba pada penelitian kali ini melibatkan 276 karakter yang terdiri dari huruf dan angka pada plat nomor kendaraan di Indonesia. Hasil uji coba menunjukkan 268 karakter diantaranya mampu dikenali dengan benar. Dengan kata lain metode yang digunakan memiliki tingkat akurasi hingga $97,10 \%$.
\end{abstract}

Kata kunci: Pengenalan plat nomor, Momentum Backpropagation Neural Network, Haar Wavelet

\section{PENDAHULUAN}

Jumlah kendaraan di Indonesia, terutama di kota-kota besar, terus mengalami kenaikan yang signifikan tiap tahunnya. Berdasarkan data milik Korps Lalu Lintas Kepolisian Negara Indonesia yang dikutip oleh situs surat kabar Kompas, pada tahun 2013jumlah kendaraan di Indonesia mencapai 104.211.000 unit, atau meningkat sebesar 11\% dibandingkan dengan tahun sebelumnya. Besarnya peningkatan jumlah kendaraan ini ikut memberikan dampak pada munculnya masalah lalu lintas seperti kemacetan lalu lintas. Kemacetan lalu lintas adalah kondisi yang terjadi ketika jumlah kendaraan di jalan melebihi kapasitas jalan, dan ditandai oleh deselerasi, keterlambatan waktu tempuh, dan antrian panjang(Olusina dan Samson, 2014). Selain kemacetan, jumlah tindak pelanggaran lalu lintas juga ikut meningkat. Salah satu solusi yang sudah diterapkan di negara-negara maju adalah Sistem Lalu Lintas Cerdas. Sistem ini dapat digunakan secara luas untuk banyak tujuan, seperti sistem manajemen tol otomatis pada jalan raya, jembatan, terowongan, manajemen kendaraantransportasi perkotaan, komunitas cerdas, manajemen parkir cerdas, validasi plat nomor, deteksi kendaraan yang dicuri, dan statistik lalu lintas (Yingyong et al., 2015).

Pengenalan plat nomor merupakan salah satu teknologi penting pada Sistem Lalu Lintas Cerdas (Shih et al., 2012). Teknologi ini memanfaatkan pengolahan citra untuk mengidentifikasi kendaraan dari citra plat nomornya (Singh dan Randhawa, 2014). Namun keragaman pada plat dan lingkungan sekitarnya seperti ukuran font, jenis font, warna font, lokasi plat nomor, dan perbedaan intensitas karena lampu atau lingkungan dapat menyebabkan masalah pada saat pengenalan plat nomor (Ramachandran et al., 2015). 
Pada penelitian kali ini akan dibahas sistem untuk mengenali karakter pada citra plat nomor kendaraan di Indonesia. Adapun algoritma yang digunakan oleh sistem pada tahappengenalan karakter plat nomor adalah algoritma Momentum Backpropagation Neural Network. Namun sebelum citra karakter masuk ke tahap pengenalan, akan digunakan Haar Wavelet untuk mereduksi dan menyeragamkan dimensi citra. Hasil dari penelitian ini diharapkan dapat menjadi awal untuk mewujudkan sistem Lalu Lintas Cerdas di Indonesia demi kenyamanan seluruh pengguna jalan.Pembahasan terkait penelitian pada artikel ini akan dibagi menjadi 5 bagian yaitu: pendahuluan yang berisi latar belakang diadakannya penelitian, kajian pustaka yang berisi pembahasan penelitian-penelitian sebelumnya dengan topik serupa, metode penelitianyang akan mengulasberbagai metode untuk penelitian kali ini, hasil dan pembahasan yang menampilkanhasil-hasil percobaan dari sistem yang diusulkan pada penelitian ini beserta pembahasannya, dan terkahir adalah kesimpulan.

\section{KAJIAN PUSTAKA}

Sejak pertama kali diciptakan oleh Cabang Pengembangan Ilmiah Polisi di Inggris pada tahun 1976, pengenalan plat nomor terus menjadi bahan penelitian yang menarik. Penelitian tidak hanya dilakukan di benua Eropa dan Amerika saja, tetapi juga sampai ke benua Asia. Seperti Singh dan Khehra (2011) yang melakukan penelitian untuk membuat sistem pengenalan plat nomor di India berbasis Backpropagation Neural Network. Sistem yang diusulkan terdiri dari 4 bagian yaitu pemrosesan awal, segmentasi, ekstraksi fitur, dan klasifikasi. Pada bagian pemrosesan awal digunakan Gausian Filter untuk mengurangi derau pada citra. Setelah itu citra hasil pemrosesan awal akan disegmentasi untuk memisahkan area-area yang mengandung karakter dengan yang tidak. Pada tahap berikutnya, citra hasil segmentasi akan diekstrak fiturnya menggunakan metode Bounding Box. Terakhir, hasil ekstraksi fitur akan dimasukkan ke bagian klasifikasi untuk dikenali. Hasil ujicoba pada penelitian ini menunjukkan sistem yang dibangun memiliki akurasi pengenalan mencapai 96\%.

Penelitian sejenis juga pernah dilakukan oleh Ganapathy dan Lui (2008) di Malaysia. Namun sistem yang dibangun pada penelitian kali ini lebih ditujukan untuk penerapan di suatu lahan parkir mobil. Citra kendaraan mula-mula diakuisisi menggunakan kamera digital. Untuk mencari lokasi plat nomor pada citra digunakan metode kombinasi antara morfologi dan Hough Transform. Setelah lokasi plat nomor pada citra diketahui, sistem akan melakukan segmentasi karakter dan mengisolasi masing-masing karakter plat nomor. Citra hasil segmentasi ini kemudian akan masuk pada bagian pengenalan karakter. Algoritma yang digunakan pada bagian pengenalan karakter adalah Feed Foorward Backpropagation Neural Network dengan 1 lapisan tersembunyi. Sistem yang diusulkan pada penelitian ini diujicobakan terhadap 589 citra karakter dan menghasilkan tingkat akurasi mencapai 95\%.

Penelitian tentang pengenalan plat nomor kendaraan juga pernah dilakukan Mai et al., (2013). Pada penelitiannya, tahapan pengenalan karakter dari sistem yang diusulkan juga memanfaatkan Jaringan Saraf Tiruan dengan algoritma Backpropagation. Perbedaan dengan penelitian sebelumnya terletak pada jumlah Jaringan Saraf Tiruan yang digunakan. Pada penelitian kali ini, digunakan dua Jaringan Saraf Tiruan yang masing-masing bertanggung jawab untuk mengenali karakter huruf dan angka pada plat nomor. Pada bagian akhir penelitian ini, diketahui bahwa efektifitas sistem yang diusulkan lebih baik dibanding sistem yang sudah ada. Selain itu, efisiensi waktu komputasi dan tingkat akurasi juga ikut meningkat.

Pendekatan yang sedikit berbeda dilakukan oleh Laxmi dan Rohil (2014). Meskipun masih memanfaatkan algoritma Backpropagation Neural Networkuntuk bagian pengenalan karakter, penelitian kali ini juga memanfaatkanHaar Waveletuntuk melakukan deteksi lokasi plat nomor dan ekstraksi karakter pada citra plat nomor.HaarWavelet akan menghasilkan 4 rincian dari citra yaitu rincian aproksimasi, vertikal, horizontal, dan diagonal. Keempat rincian ini akan memberikan informasi yang lengkap untuk membantu sistem mendeteksi lokasi plat nomor dan ekstraksi karakter dari citra. Menurut hasil eksperimen, metode yang diusulkan pada penelitian ini berhasil menemukan lokasi plat nomor dari citra lingkungan yang kompleks. Hal ini sekaligus menunjukkan kelayakan sistem yang diusulkan.

Berdasarkan beberapa penelitian yang sudah pernah dilakukan sebelumnya, penulis mengusulkan sistem yang mampu mengenali plat nomor kendaraan di Indonesia. Pada sistem 
yang diusulkan kali ini akan digunakan varian dari algoritma Backpropagation yaitu Momentum Backpropagation Neural Network. Selain itu, akan digunakan juga metode Haar Wavelet untuk mereduksi dan menyeregamkan ukuran citra karakter hasil segmentasi yang akan dikenali. Penggunaan Haar Wavelet diharapkan mampu meringankan beban komputasi pada bagian pengenalan karakter. Adapun penjelasan lebih detil terkait sistem yang diusulkan pada penelitian ini akan dibahas pada bagian selanjutnya

\section{METODE PENELITIAN}

Pada artikel ini, peneliti mengusulkan sistem untuk mengenali karakter yang ada pada citra plat nomor kendaraan di Indonesia. Adapun gambaran umum dari sistem yang diusulkan seperti yang terlihat pada Gambar 1 dibawah ini.

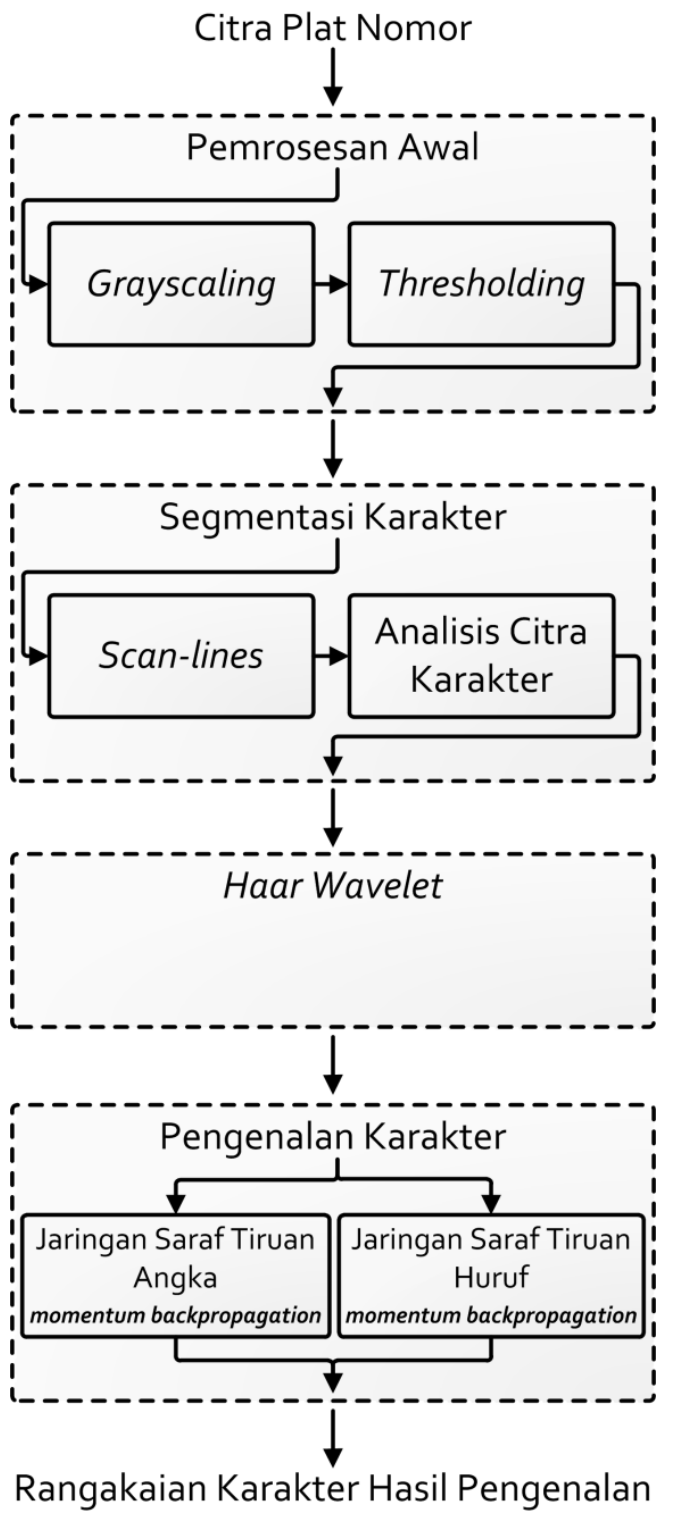

Gambar 1. Gambaran Umum Sistem

Mula-mula sistem akan menerima inputan berupa citra plat nomor berformat RGB atau full color. Citra plat nomor adalah citra yang hanya mengandung bagian plat nomor dari suatu kendaraan tanpa ada objek lain.Langkah selanjutnya adalah melakukan pemrosesan awal pada citra plat nomor yaitu grayscaling dan thresholding. Langkah ini akan mengubah citra input RGB menjadi citra grayscale.Grayscalingadalah proses untuk menghasilkan citraaras keabuan dari citra berwarna (Ibrahim et al., 2013). Sedangkan thresholding adalah proses untuk 
mengubah citra aras keabuan menjadi citra biner atau citra yang hanya terdiri dari warna hitam dan putih. Thresholding digunakan untuk memisahkan objek dari latar belakang, mengurangi derau pada citra, danmeningkatkan kecepatan komputasi pada tahapan berikutnya. Penentuan nilai piksel pada saat thresholding mengikuti rumus berikut:

$$
f(x, y)^{\prime}=\left\{\begin{array}{l}
0, f(x, y)<T \\
1, f(x, y) \geq T
\end{array}\right.
$$

Bila nilai piksel kurang dari nilai threshold Tmaka nilai piksel akan diubah menjadi 0 atau hitam. Sebaliknya jika nilai piksel lebih dari atau sama dengan nilai threshold Tmaka piksel akan menjadi warna putih.Pada akhir langkah ini akan dihasilkan citra biner dari citra inputan.

\subsection{Segmentasi Karakter}

Setelah citra biner hasil pemrosesan awal didapatkan, langkah berikutnya adalah melakukan segmentasi karakter.Langkah ini adalah langkah yang paling penting dalam pengenalan plat nomor karena menentukan hasil langkah-langkah berikutnya (Solanki et al., 2013).Jika segmentasi gagal, karakter terbagi menjadi dua bagian, atau dua karakter dapat bergabung secara tidak benar (Tatale danKhare, 2011). Dengan kata lain, hasil segmentasi yang buruk akan menurunkan kemungkinan karakter untuk dikenali dengan tepat.Pada penelitian kali ini, segmentasi karakter pada citra plat nomor dilakukan dengan metode scan-lines untuk mencari batas atas dan batas bawah dari rangkaian karakter yang ada pada plat nomor. Kemudian dari batas atas dan bawah yang didapatkan, sistem akan mulai mengisolasi tiap karakter, dengan menentukan batas kiri dan kanan untuk setiap karakter yang ada pada citra.

Setelah mendapatkan citra individu dari tiap karakter pada plat nomor, sistem akan melakukan analisis untuk memastikan citra yang akan dikenali pada tahapan selanjutnya adalah citra karakter. Analisis dilakukan dengan memperhatikan rasio ukuran panjang dan lebar dari karakter plat nomor, serta jumlah piksel putih pada citra hasil segmentasi. Hasil dari langkah kedua ini adalah citra individu dari karakter-karakter yang ada pada plat nomor.

\subsection{Haar Wavelet}

Sebelum masuk pada bagian pengenalan karakter, citra karakter hasil segmentasi akan di proses menggunakan alihragam Haar Wavelet.Haar Wavelet adalah salah satu transformasi yang paling sederhana dan menjadi dasar transformasi dari domain ruang ke domain frekuensi(Ghorpade dan Katkar, 2014). Karena sifatnya yang sederhana ini, Haar Wavelet tidak membutuhkan waktu yang lama untuk melakukan transformasi pada citra, sehingga tidak menambah beban komputasi pada sistem.Haar Wavelet akan mendekomposisi citra menjadi 4 bagian seperti pada Gambar 2 berikut.

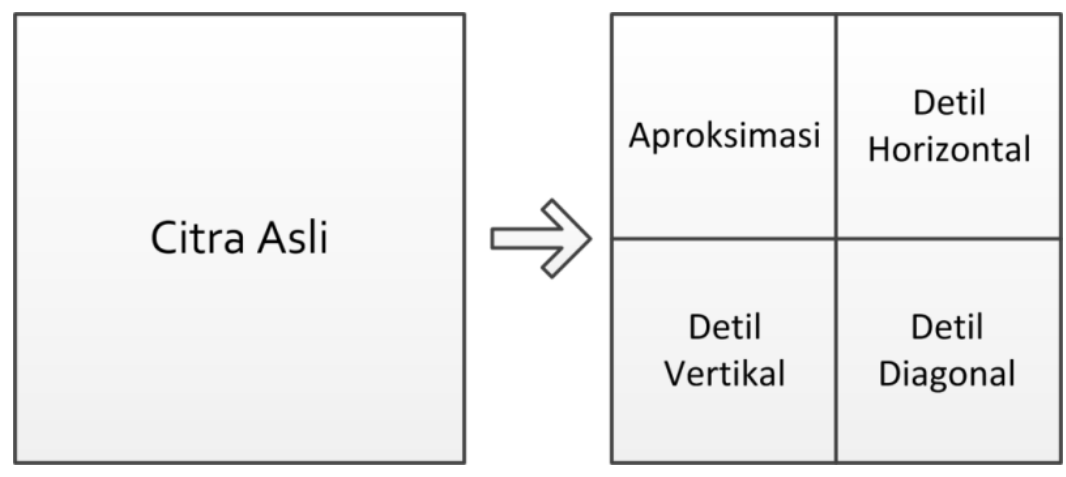

Gambar 2. Dekomposisi Wavelet

Bagian aproksimasi berisi komponen frekuensi rendah arah vertikal danhorizontal. Pada bagian kiri bawah atau detil vertikalakan berisi komponen frekuensi rendah arah horizontal danfrekuensi tinggi arah vertikal. Sedangkan bagian detil horizontal berisi komponen frekuensi 
tinggi horizontal danfrekuensi rendah vertikal. Terakhir bagian detil diagonal berisi komponen frekuensi tinggi baikpada arah horizontal maupun vertikal.

Pada peneltian ini,Haar Wavelet akan digunakan untuk mereduksi dan menyeragamkan ukuran citra karakter yang nanti akan dikenali oleh Jaringan Saraf Tiruan.Bagian aproksimasi yang dihasilkan dari dekompoisis Haar Wavelet pada citra segmentasi akan menjadi keluaran pada langkah ini. Sehingga di akhir langkah ini, citra-citra karakter hasil segmentasi dengan ukuran yang sama yaitu $32 \times 32$ piksel akan dihasilkan.

\subsection{Pengenalan Karakter}

Pada langkah terakhir dari sistem yang diusulkan ini, citra karakter dari langkah sebelumnya akan dikenali menggunakan Jaringan Saraf Tiruan. Jaringan Saraf Tiruan adalah sekumpulan nodeyang saling terhubung, serupa dengan jaringan neuron yang luas di otak (Bhushan et al., 2013).Penggunaan Jaringan Saraf Tiruan dalam aplikasi pengenalan karakter dapat menyederhanakan kode secara dramatis dan meningkatkan kualitas pengenalan sehingga dapat mencapai kinerja yang baik (Patel., 2013).Selain itu, kelebihan lainnya dari Jaringan Saraf Tiruan adalah sifatnya yang sangat tahan terhadap noise (Varshney et al., 2014).Secara umum, arsitektur dari Jaringan Saraf Tiruan terdiri dari 3 lapisan seperti yang ditampilkan pada Gambar 3 berikut ini.

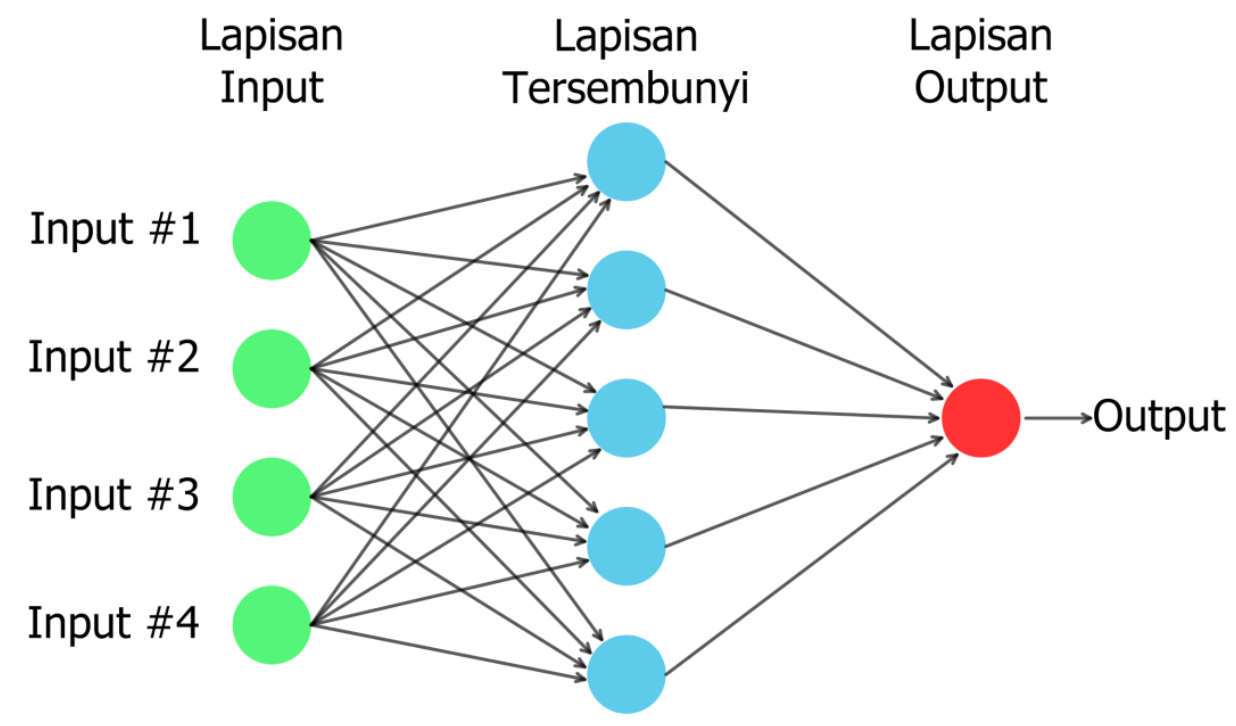

Gambar 3. Arsitektur Jaringan Saraf Tiruan

Seperti yang terlihat pada Gambar 3 di atas, suatu Jaringan Saraf Tiruan terdiri dari tigajenis lapisan yaitu lapisan input, lapisan tersembunyi dan lapisan output. Masing-masing lapisan terdiri dari sejumlah nodeyang digambarkan dengan lingkaran.Untuk tiap node di masing-masing lapisanakan selalu terhubung dengan node pada lapisan berikutnya.

Secara umum, semua metode pembelajaran yang digunakan untuk Jaringan Saraf Tiruan dapat diklasifikasikan ke dalam dua kategori utama: pembelajaran terbimbing dan pembelajaran tak terbimbing(Khushbu dan Mehta, 2013).Perbedaan utamanya adalah, pada kasus pembelajaran terbimbing menggunakan data pelatihan input-output untuk memodelkan sistem dinamis, di sisi lain, pada kasus pembelajaran tanpa pengawasan hanya input data yang diberikan (Melin dan Castillo, 2007). Pada penelitian kali ini, akan digunakan salah satu algoritma pelatihan jaringan terbimbing yaitu Momentum Backpropagation.

\subsection{Algoritma Momentum Backpropagation}

Algoritma pelatihan jaringan Momentum Backpropagation merupakan modifikasi dari algoritma Backpropagation yang dikembangkan Mc Clelland pada tahun 1988. Untuk itu secara garis besar langkah yang ditempuh pada algoritma ini sama dengan yang ada pada algoritma Backpropagation. 
Algoritma dimulai dengan menjalankan tahap propagasi maju yaitu mengirimkan nilai pada node input ke setiap node yang ada pada lapisan tersembunyi untuk kemudian dihitung menggunakan fungsi aktivasi berikut:

$$
z_{j}=f\left(v_{0 j}+\sum_{i=1}^{n} x_{i} v_{i j}\right)
$$

Hasil dari perhitungan tersebut kemudian akan dikirim ke seluruh node lapisan berikutnya, yaitu lapisan output. Di lapisan output, masing-masing node juga akan menghitung menggunakan fungsi aktivasi dengan rumus:

$$
y_{k}=f\left(w_{0 k}+\sum_{j=1}^{p} z_{j} w_{j k}\right)
$$

Setelah sampai lapisan output, akan dijalankan tahap propagasi mundur yang akan menghitung informasi kesalahan $\delta_{k}$ berdasarkan pola target $t_{k}$ yang diterima lapisan output. Informasi kesalahan ini nantinya akan digunakan untuk mengoreksi bobot $\Delta w_{j k}$ pada lapisan sebelumnya dengan rumus:

$$
\begin{aligned}
& \delta_{k}=\left(t_{k}-y_{k}\right) f^{\prime}\left(w_{0 k}+\sum_{j=1}^{p} z_{j} w_{j k}\right) \\
& \Delta w_{j k}=\alpha \delta_{k} z_{j}
\end{aligned}
$$

Hal yang sama juga dilakukan untuk mencari informasi kesalahan pada lapisan tersembunyi dan mengoreksi bobot antara lapisan tersembunyi dengan lapisan input $\Delta v_{i j}$.

Perbedaan terletak pada tahap terakhir yaitu penyesuaian bobot. Untuk algoritma Momentum Backpropagation, di tahap ini ditambahkan satu parameter baru yaitu momentum yang dilambangkan dengan $\beta$.Sehingga rumus untuk tahap penyesuaian bobot pada algoritma Momentum Backpropagationini menjadi seperti berikut:

$$
\begin{aligned}
& w_{j k(\text { baru })}=w_{j k(\text { lama })}+\Delta w_{j k}+\left(\beta \Delta w_{j k(\text { lama })}\right) \\
& v_{i j(\text { baru })}=v_{i j(\text { baru })}+\Delta v_{i j}+\left(\beta \Delta v_{i j(\text { lama })}\right)
\end{aligned}
$$

Penambahan parameter momentum ke dalam Jaringan Saraf Tiruan bertujuan mempercepat proses pembelajaran menuju konvergen.Hasil percobaan juga telah menunjukkan bahwa metode ini dapat membuat jaringan mencapai konvergen dengan cepat dan stabil, serta meningkatkan kecepatan dan akurasi identifikasi karakter plat (Anju dan Bhudiraja, 2011). Selain dapat mencapai konvergen dengan lebih cepat, penggunaan momentum juga dapat menghindarkan jaringan dari keadaan stuck pada nilai minimum lokal (Rehman dan Nawi, 2011).Hal ini disebabkan karena momentum memungkinkan jaringan untuk melakukan penyesuaian bobot secara drastis selama hasil penyesuaian ke arah yang sama pada beberapa pola (Tawade dan Warpe, 2011).Dengan demikian, waktu yang dibutuhkan untuk melakukan pelatihan pada jaringan juga semakin cepat.

\section{HASIL DAN PEMBAHASAN}

Pada bagian ini akan dijabarkan hasil percobaan terhadap sistem yang diusulkan disertai dengan pambahasannya. Dimulai dari citra plat nomor yang akan dijadikan input ke dalam sistem. Citra plat nomor yang digunakan sebagai inputan sistem adalah citra yang hanya mengandung plat nomor, tanpa ada objek lain. Adapun contoh dari citra input pada penelitian kali ini, seperti yang tampak pada Gambar 4 dibawah ini. 


\section{AE 559 BKAB 1818 V]}
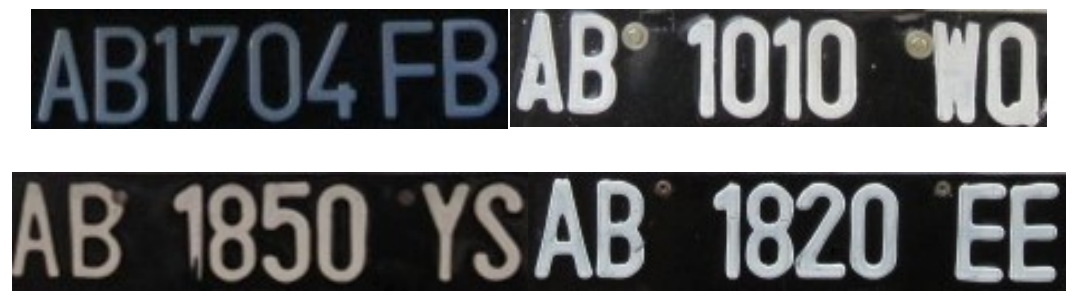

Gambar 4. Contoh citra plat nomor sebagai inputan sistem

Dari gambar di atas, tampak bahwa citra plat nomor yang digunakan sebagai inputan sistem memiliki tingkat kecerahan yang berbeda-beda. Hal ini dipengaruhi oleh pencahayaan dari lingkungan sekitar saat pengambilan gambar. Pada penelitian kali ini, pengambilan gambar dilakukan pada waktu pagi hari saat matahari belum terlalu tinggi, siang hari saat matahari tepat berada di atas, dan sore hari saat matahari akan terbenam. Setelah mendapatkan citra input, selanjutnya sistem akan melakukan pemrosesan awal. Adapun hasil dari pemrosesan awal adalah seperti Tabel 1 berikut.

Tabel 1. Citra hasil pemrosesan awal

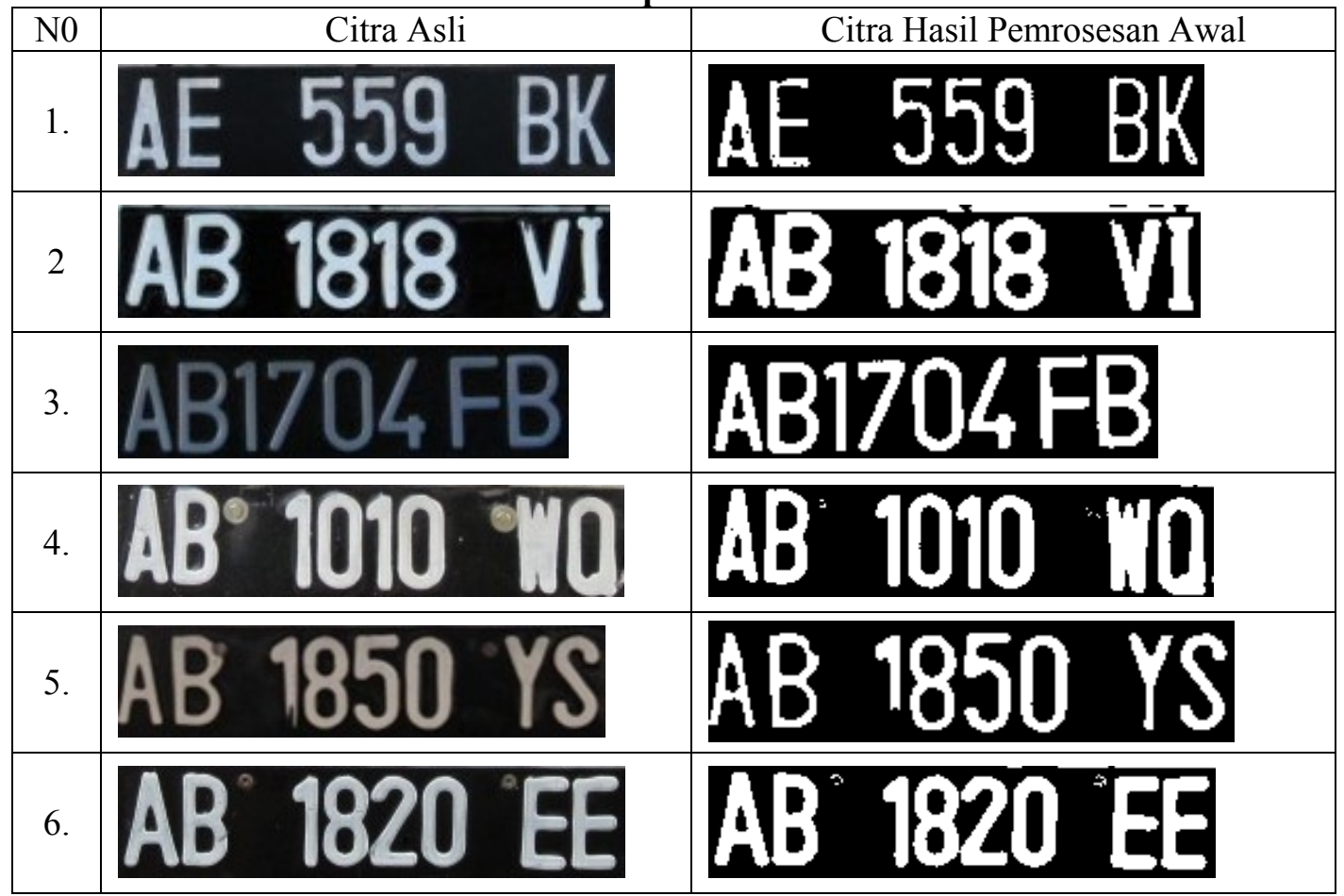

Dari Tabel 1, terlihat bahwa citra input yang tadinya berformat full color, setelah melalui tahap pemrosesan awal, tinggal menyisakan warna hitam dan putih saja. Namun untuk beberapa plat nomor yang memiliki kualitas pewarnaan kurang baik, seperti pada citra nomor 5 pada Tabel 1, tahap pemrosesan awal membuat sebagian karakter angka 1 yang ada pada citra plat nomor menghilang. Selain itu, pada beberapa citra di Tabel 1, masih nampak objek baut pada citra hasil pemrosesan awal. Ini kemudian menjadi tugas dari langkah berikutnya yaitu segmentasi karakter, untuk menentukan objek karakter dan objek bukan karakter pada citra. Adapun hasil dari segmentasi karakter seperti pada Tabel 2 di bawah ini. 
Tabel 2. Citra hasil segmentasi karakter

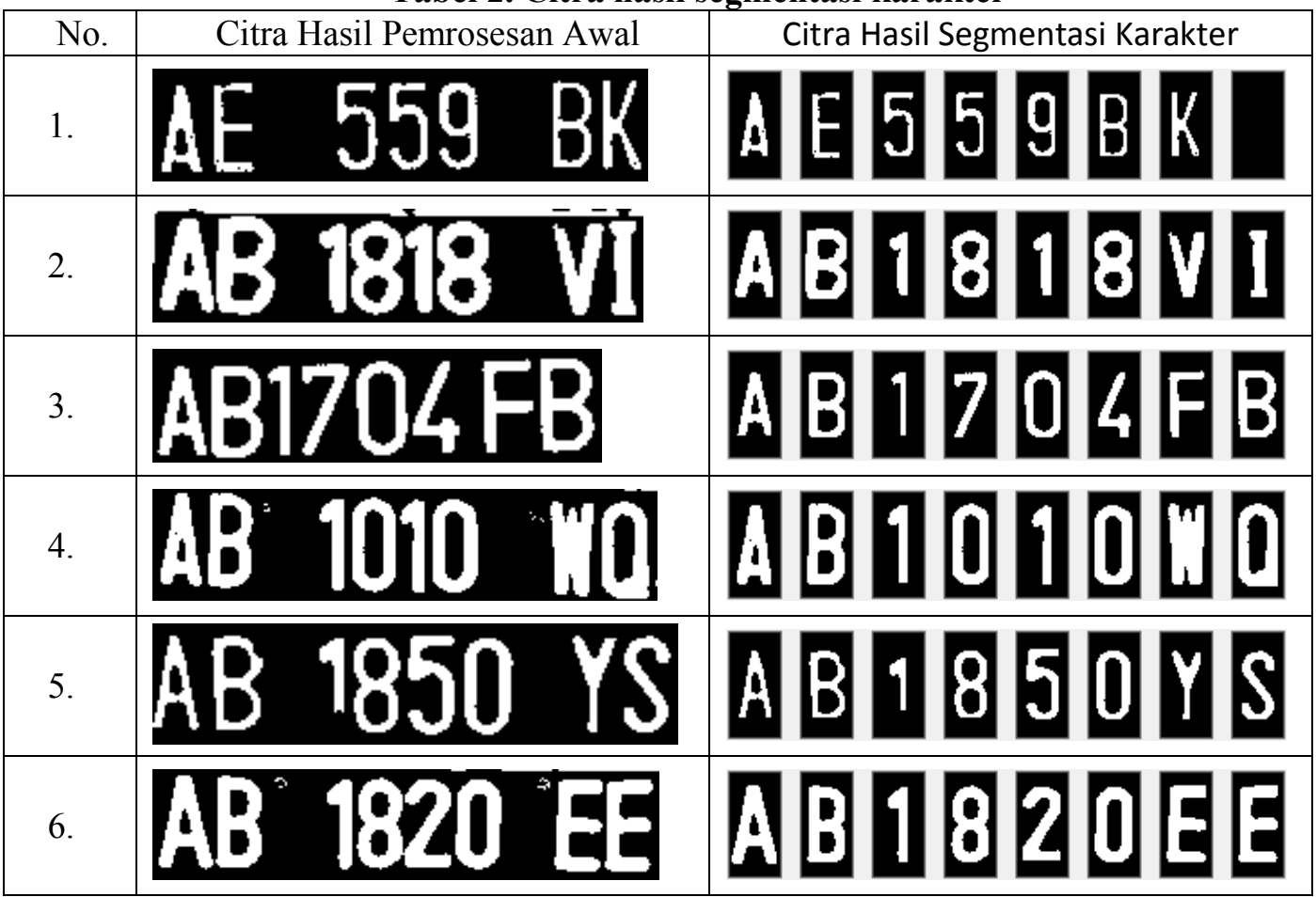

Berdasarkan citra hasil segmentasi karakter pada Tabel 2 di atas, dapat diketahui sistem yang diusulkan mampu melakukan segmentasi dengan tepat. Hal ini terbukti dari tidak adanya objek baut yang dikenail sebagai karakter. Setelah citra individu dari tiap karakter didapatkan, langkah berikutnya adalah melakukan transformasi menggunakan Haar Wavelet pada setiap citra karakter. Adapun contoh hasil dari transformasi menggunakan Haar Wavelet seperti yang terlihat pada Gambar 5 berikut.

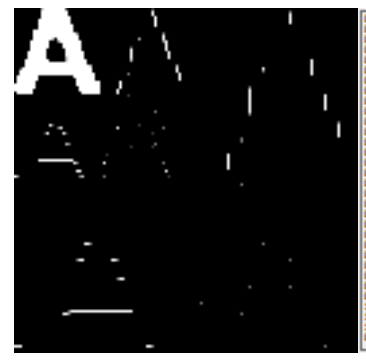

(a)

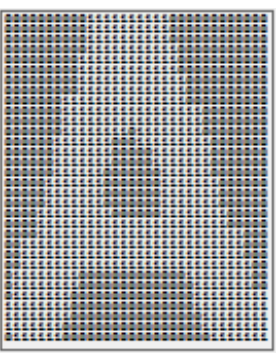

(b)

Gambar 5. Hasil transformasi Haar Wavelet (a) Hasil transformasi Haar Wavelet 2 level untuk karakter huruf A, (b) Matriks input karakter huruf A berukuran $32 \times 32$

Transformasi Haar Waveletpada masing-masing citra karakter hasil segmentasi nantinya akan menghasilkan matriks berukuran $32 \times 32$. Matriks ini kemudian diubah menjadi vektor berukuran 1024 dan selanjutnya akan menjadi nilai inputan untuk setiap node yang berada di lapisan input pada Jaringan Saraf Tiruan (JST).

Untuk langkah terakhir pada penelitian ini, yaitu pengenalan karakter, digunakan dua jaringan yang masing-masing bertugas untuk mengenali karakter huruf dan angka.Penggunaan dua jaringan ini bertujuan untuk menghindarkan sistem dari kesalahan pengenalan yang sering terjadi pada sistem pengenalan karakter dengan satu jaringan,terutama untuk karakter angka dan huruf yang memiliki bentuk serupa, seperti karakter angka "1" dikenali sebagai huruf "I" dan sebaliknya. Hal ini dikarenakan, pada sistem yang menggunakan dua jaringan, pelatihan masing-masing jaringan akan terfokus untuk salah satu jenis karakter saja yaitu huruf atau angka. 
Arsitektur dari JST yang digunakan pada penelitian kali ini terdiri dari 1 lapisan input, 2 lapisan tersembunyi, dan 1 lapisan output. Jumlah node pada lapisan input untuk kedua jaringan sama yaitu 1025, yang didapatkan dari dimensi vektor karakter ditambah satu node bias. Begitu juga pada lapisan tersembunyi jumlah node yang digunakan pada JST angka dan huruf sama yaitu 30 node untuk lapisan tersembunyi pertama dan 20 node untuk lapisan tersembunyi kedua.Namun lain halnya pada lapisan output, yang mana JST angka membutuhkan 4 node untuk mengenali 10 karakter angka (0-9), sedangkan JST huruf membutuhkan 5 node untuk mengenali 26 karakter huruf (A-Z).

Uji coba pengenalan karakter dilakukan dengan melibatkan 139 karakter angka dan 137 karakter huruf. Percobaan juga dilakukan dengan mengganti konfigurasi nilai laju belajar atau $\alpha$ dan momentum atau $\beta$. Adapun hasil dari pengujian sistem yang diusulkan seperti yang tertera pada Tabel 3 berikut.

Tabel 3. Hasil pengujian pengenalan karakter

\begin{tabular}{|l|c|c|c|c|c|c|c|}
\hline & \multicolumn{2}{|c|}{ JST Angka } & \multicolumn{2}{|c|}{ JST Huruf } & $\begin{array}{c}\text { Angka } \\
\text { Dikenali }\end{array}$ & $\begin{array}{c}\text { Huruf } \\
\text { Dikenali }\end{array}$ & \\
\cline { 2 - 8 } & $\alpha$ & $\beta$ & $\alpha$ & $\beta$ & & & \\
\hline 1. & 0,2 & 0,9 & 0,2 & 0,7 & $138 / 139$ & $129 / 137$ & 96,74 \\
\hline 2. & 0,2 & 1,0 & 0,2 & 1,0 & $139 / 139$ & $121 / 137$ & 94,20 \\
\hline 3. & 0,2 & 0,7 & 0,2 & 0,7 & $139 / 139$ & $129 / 137$ & 97,10 \\
\hline
\end{tabular}

Pada percobaan pertama digunakan konfigurasi $\alpha$ dan $\beta$ untuk jaringan angka adalah 0,2 dan 0,9 sedangkan untuk jaringan huruf adalah 0,2 dan 0,7. Dari konfigurasi tersebut, diketahui 138 dari 139 karakter angka dapat dikenali dan 129 dari 137 karakter huruf dapat dikenali. Pada percobaan kedua, konfigurasi nilai $\beta$ diubah menjadi 1,0 untuk kedua jaringan, sedangkan nilai $\alpha$ masih sama seperti percobaan pertama. Hasildari percobaan kedua ini mampu mengenali seluruh karakter angka yang diujikan dengan benar,tetapi hanya mampu mengenali 121 karakter huruf dari total 137 karakter yang diujikan. Percobaan ketiga, menggunakan konfigurasi yang sama untuk jaringan angka dan huruf yaitu 0,2 untuk $\alpha$ dan 0,7 untuk $\beta$. Konfigurasi pada percobaan ketiga ini, menghasilkan tingkat akurasi terbaik yaitu $97,10 \%$ setelah mampu mengenali seluruh karakter angka yang diujikan dan mampu mengenali 129 dari total 137 karakter huruf yang diujikan.

\section{KESIMPULAN}

Berdasarkan hasil pengujian terhadap sistem yang diusulkan, dapat ditarik kesimpulan bahwa sistem mampu melakukan pengenalan pola dengan baik. Hal ini terbukti dari keandalan sistem dalam melakukan segmentasi karakter plat nomor, yang akan sangat berpengaruh pada langkah selanjutnya yaitu pengenalan karakter menggunakan Jaringan Saraf Tiruan. Selain itu tahap pengenalan karakter menggunakanalgoritma Momentum Backpropagationjuga memberikan hasil yang menjanjikan. Akurasi pengenalan karakter yang terbaik pada penelitian kali ini didapatkan dengan konfigurasi nilai laju belajar $\alpha=0,2$ dan momentum $\beta=0,7$ untuk kedua jaringan. Hasilnya, dari total 276 karakter yang terdiri dari huruf dan angka, sistem mampu mengenali 268 karakter diantaranya. Sehingga akurasi sistem yang diusulkan pada penelitian kali ini mencapai 97,01\%.Meskipun hasil yang didapatkan sudah cukup memuaskan, untuk masa yang akan datang masih diperlukan penelitian tentang pengenalan karakter plat nomor kendaraan terutama untuk mengenali karakter plat nomor pada kendaraan yang sedang bergerak bahkan dalam kecepatan tinggi. 


\section{DAFTAR PUSTAKA}

Anju and Budhiraja, S.,2011. A Review of License Plate Detection and RecognitionTechniques. In National Workshop-Cum-Conference on Recent Trends in Mathematics and Computing. India. 2011.

Bhushan, B., Singh, S. and Singla, R., 2013. License Plate Recognition System using NeuralNetworks and Multithresholding Technique.International Journal of Computer Applications, 84(5), pp.45-50.

Ganapathy, V. andLui, W.L.D., 2008. A Malaysian Vehicle License Plate Localization and Recognition System. Journal of Systemics, Cybernetics and Informatics, 6(1), pp.13-20.

Ghorpade, A. and Katkar, P., 2014.Image Compression Using Haar Transform AndModified Fast Haar Wavelet Transform.International Journal of Scientific \& Technology Research, 3(7), pp.302-305.

Ibrahim, N.K., Kasmuri, E., Jalil, N.A., Norasikin, M.A., Salam, S. and Nawawi, M.R.M., 2013.License Plate Recognition (LPR): A Review withExperiments for Malaysia Case Study.The International Journal of Soft Computing and Software Engineering, 3(3), pp.83-93.

Khushbu and Mehta, S., 2014.Image Pre-processing on Character Recognition usingNeural Networks.International Journal of Computer Applications, 82(13), pp.11-15.

Kurniawan, Agung. 2014. Populasi Kendaraan Bermotor di Indonesia Tembus 104,2 Juta Unit. [Online] available

at: http://otomotif.kompas.com/read/2014/04/15/1541211/Populasi.Kendaraan.Bermotor.di .Indonesia.Tembus.104.2.Juta.Unit[Accessed 23 November 2015].

Laxmi, V. and Rohil, H., 2014.License Plate Recognition System using BackPropagation Neural Network.International Journal of Computer Applications, 99(8), pp.29-37.

Mai, V.D., Miao, D. and Wang, R., 2013. Vietnam License Plate Recognition Systembased on Edge Detection and Neural Networks.Journal of Information and Computing Science, 7(1), pp.27-40.

Melin, P. and Castillo, O., 2007. Hybrid Intelligent System for Pattern Recognition.Journal of Automation, Mobile Robotics \& Intelligent Systems, 1(2), pp.13-19.

Olusina, J.O. and Samson, A.P., 2014.Determination of Predictive Models for TrafficCongestion in Lagos Metropolis.International Journal of Engineering and Applied Sciences, 5(2), pp.25-35.

Patel, S.G., 2013. Vehicle License Plate Recognition Using Morphology and Neural Network.International Journal on Cybernetics \& Informatics, 2(1), pp.1-7.

Ramachandran, R., Manivannan, R., Ramachandiran, R. and Balachandar, N., 2015. Cloud Based Real Time Anti Vehicle Theft By Using LP Recognition And OCR Recognition. International Journal Of Engineering And Computer Science, 4(3), pp.10779-10786.

Rehman, M.Z. and Nawi, N.M., 2011. Improving the Accuracy of Gradient Descent Back PropagationAlgorithm (GDAM) on Classification Problems. International Journal on New Computer Architectures and Their Applications, 1(4), pp.838-847.

Shih, B., Chen, C., Chen, C., and Kuo, J., 2012.A Robust License Plate Recognition Methodology by Applying Hybird Artificial Techniques. International Journal of Innovative Computing,Information, and Control, 8(10), pp.6777-6785.

Singh, D. andKhehra, R.S., 2011. Digit Recognition System Using Back Propagation Neural Network. International Journal of Computer Science and Communication, 2(1), pp.197205.

Singh, R.V. and Randhawa, N., 2014.Automobile Number Plate Recognition AndExtraction Using Optical Character Recognition. International Journal of Scientific \& Technology Research, 3(10), pp.37-39.

Solanki, R., Rai, R. and Raikwar, T., 2013. The Automatic License Plate Recognition(ALPR).International Journal of Research in Engineering and Technology, 2(7), pp.161-167. 
Tatale, S.and Khare, A., 2011, Real Time ANPRfor Vehicle Identification UsingNeural Network.International Journal of Advances in Engineering \& Technology, 1(4), pp.262-268.

Tawade, L. and Warpe, H., 2011. Detection of Epilepsy Disorder Using Discrete Wavelet TransformsUsing MATLABs. International Journal of Advanced Science and Technology, 28(3), pp.17-24.

Varshney, S., Chaurasiya, R. and Tayal, Y., 2014.Optical Character Recognition using Neural Network.International Journal of Emerging Technology and Advanced Engineering, 4(8), pp.711-715.

Yingyong, Z., Jian, Z., Yongde, Z., Xinyan, C., Guangbin, Y. and Juhui, C., 2015.Research on Algorithm for Automatic License Plate Recognition System. International Journal of Multimedia Ubiquitous Engineering, 10(1), pp.101-108. 